\title{
Academic Achievement of Primary School Pupils: Investigating Home Environment Factors Contributing to Low Academic Performance
}

\begin{abstract}
Home environment factors affect the mental and psychological capability of the learner to attain academic feats. This study investigated home environment factors contributing to low academic performance in primary school pupils in Ghana focusing on the Kwame Nkrumah University of Science and Technology (KNUST) Primary School in Kumasi. Home environment factors include socio-economic status, parental style and family size. Qualitative and quantitative data were collected from 120 learners and 60 parents of the institution using questionnaires and interview respectively. The results revealed that a significant number of pupils described their homes as not conducive for learning and this was largely attributed to the parental socio-economic status. Again, lack of parental involvement negatively influences the academic work of learners. The study concluded that parents should be encouraged to participate in regular Parent Teacher Association (PTA) meetings to learn more about parental styles and strategies to be more involved in their children's education.
\end{abstract}

Keywords: Home environment factors, academic achievement, academic performance, socioeconomic status, parental style.

\author{
OLIVIA AKROFI ${ }^{1}$ \\ ${ }^{1}$ Olivia Akrofi is a Chief Teacher at \\ Kwame Nkrumah University of Science \\ and Technology (KNUST) Primary \\ School. She holds a Master of \\ Philosophy (Educational Innovation \\ and Leadership Science) from KNUST, \\ Kumasi-Ghana and a Master of \\ Education (Guidance and Counseling) \\ University of Cape Coast, Ghana. \\ Email: ooakrofi@gmail.com
}

Manuscript

Received 23rd March 2020,

Accepted 26th May 2020,

Published online 3rd June 2020.

\section{INTRODUCTION}

Formal education is evaluated using academic performance and it is based on this that a learner is promoted to a higher class on the academic ladder. Low academic performance is therefore a great concern for learners, teachers, parents and other stakeholders in the educational system. ${ }^{2}$ Academic performance is a huge challenge to learners because it is a product of their socio-economic, psychological and environmental interactions. Hence, the need for a strong and comprehensive foundation of both basic and second cycle education to produce highly educated and competent individuals who are well equipped for the socio-economic and political development of the nation.

The home environment to a large extent contributes to the personality and psychosocial background of a learner that influences how well he or she performs in school. ${ }^{3}$ Schools are working independently without considering the home environment factors influencing academic performance. ${ }^{4}$ Gabriel et al. are of the view that home environment refers to parents and children in the confines of the home where children are provided with basic developmental needs. Home environment factors that affect learning include: socio-economic status (SES), parental style, and family size. ${ }^{5}$

Based on this background, this study sought to investigate home factors accounting for low academic performance among pupils in primary school and recommend measures that can be taken to improve the situation. The

\footnotetext{
Luke, Mphale Moloko, and Mavis B. Mhlauli. "An investigation on students' academic performance for junior secondary schools in Botswana." European Journal of Educational Research 3, no. 3 (2014): 111-127.

3 Mary N. Gabriel, Lewis M. Ngesu, Isaac Muasya, Timothy Maonga, and Maira J. Mukhungulu. "Parental socio economic status academic achievement in selected secondary schools in urban informal settlements in Westlands Division, Nairobi County." (2016).

Olivia Akrofi. "Parental involvement in school guidance and counselling of the adolescent". University of Cape Coast, Cape Coast Ibid.
} 
study was focused on the Kwame Nkrumah University of Science and Technology Primary School.

\section{SOCIO-ECONOMIC STATUS OF PARENTS}

The socio-economic status (SES) of parents or guardians directly affects learners' academic performance. Aliyu stated that the most persuasive factor that contributes to successful learning in school is the learner's family socio-economic status. SES is the social and economic standing of a person or a family established on income, occupation and education and can be categorised into low, middle and high. ${ }^{6}$

Numerous studies have been conducted on the relationship between SES of parents or guardians and the academic achievement of children or wards. It has been revealed that parental socio-economic status does not directly affect academic performance of children. Ogunshola et al. discovered that two variables; parents' educational qualification and children's health statuses, affect children's academic performance by influencing the home environment factors. ${ }^{7}$ Parents with high SES are more capable of preparing their children for school through the provision of the essential psychological and learning resources. ${ }^{8}$ They are also more willing to collaborate with the school when it comes to the learner's needs and this kindles the interest of learning in the child.

\section{PARENTAL EDUCATION AND INCOME}

Nyarko opines that social background influences parents' involvement in their children's academic achievements. ${ }^{9}$ Parents who are educated and have high occupational status usually have the skills to help their children to do their homework and encourage them to study. They also serve as role models for their children's own educational /occupational aspirations. ${ }^{10}$

Research has shown that one's level of income usually increases as one attains higher education. ${ }^{11}$ Wealth disparities in education is a worldwide phenomenon. According to Chowa et al., in Ghana and Cote d'Ivoire, limited family income and resources reduce investment in education including further education. ${ }^{12}$ Barry asserts that the situation is similar in the USA where a study established that parental education was directly proportional to their income. Education is considered as the key to upgrading one's socio-economic status. ${ }^{13}$ It has become increasingly important to further one's training/education as a way of promoting career competence and success since additional skills and knowledge attracts added income. In addition, education also provides the opportunity for higher status, financial and personal rewarding careers. ${ }^{14}$

Highly educated parents are likely to raise their children in an academic culture and adequately provide learning resources than those raised by uneducated parents. ${ }^{15}$ Availability of textbooks, equipment, and pleasant atmosphere supports academic achievement to higher levels. Home cultures and atmosphere, to a large extent, influence learner's academic performance. ${ }^{16}$

Adane agrees that educated parents kindle the interest of learning in the child by providing school-related materials such as stationery, computer, story books and others. ${ }^{17}$ Sirin shares the opinion that, the influence of parents on African American students' academic performance can be traced particularly to certain socio-demographic factors including socio-economic status of parents. ${ }^{18}$ In addition, children from high socio-economic background are more

${ }^{6}$ Femi Ogunshola and A. Adewale. The effects of parental socioeconomic status on academic performance of students in selected schools in

Edu Lga of Kwara state Nigeria, International Journal of Academic Research of Business and Social Sciences, 2(7), $230-239$.

Ibid

8 R. G. Memon, F. M. Joubish, and A. M. Khurram. "Impact of parental socio-economic status on students" educational achievements at secondary schools of district Malir, Karachi." Middle-East Journal of Scientific Research 6, no. 6 (2010): 678-687.

9 Kingsley Nyarko. "Parental school involvement: The case of Ghana." Journal of Emerging Trends in Educational Research and Policy Studies 2, no. 5 (2011): 378-381.

10 Mary N. Gabriel, Lewis M. Ngesu, Isaac Muasya, Timothy Maonga, and Maira J. Mukhungulu. "Parental socio economic status academic achievement in selected secondary schools in urban informal settlements

${ }_{11}$ Selcuk R. Sirin, "Socioeconomic status and academic achievement: A meta-analytic review of research." Review of educational research 75, no. 3 (2005): 417-453.

12 Gina Chowa, "How Do Student and School Characteristics Influence Youth Academic Performance in Ghana? A Hierarchical Linear Modeling of Baseline Data from the Youth save Ghana Experiment." (2013).

13 Jennifer Barry, "Effects of socio-economic status on academic performance." An unpublished MA thesis submitted to Wichita State University, Australia (2005).

14 Meshach Muruwei, "Parents' level of education and Senior Secondary Students' Academic Performance in English Language in Bayelsa State, Nigeria." Journal of Research in national development 9, no. 2 (2011): 302-305.

15 Ibid

16 Daniel Yelkpieri, "Socio-economic status of parents and its effects on students' achievement in the Awutu Senya and Effutu educational directorates in the central region of Ghana." Unpublished Thesis (2016).

17 Linda Ofosua Adane, "Factors affecting low academic achievement of pupils in Kemp Methodist Junior High School in Aburi, Eastern region." PhD diss., University of Ghana, 2013.

18 Selcuk R. Sirin, "Socioeconomic status and academic achievement: A meta-analytic review of research." Review of educational research 75, no. 3 (2005): 417-453. 
likely to enjoy better learning environment at home than their counterparts from low socio-economic status.

One's educational status has a direct link with prospects in life, income and standard of living. ${ }^{19}$ It is believed that unstable work and unemployment can be psychologically stressful for some parents because it obstructs their emotional warmth and love for the family. Pupils from low socio-economic background could be emotionally unsound as a result of financial constraints. This consequently affects their motivation for learning. ${ }^{20}$

Many people consider employment opportunities as economic and financial security. Hence, parents who are gainfully employed should be in a better position to cater for their children's education. ${ }^{21}$ Parents' occupation have both positive and negative repercussions on children as agreed by subsequent researchers. ${ }^{22}$ Gabriel et al. argued that sufficient income enables parents to adequately cater for the developmental needs of their children. ${ }^{23}$

Parents are responsible for providing the basic necessities of life: adequate food, shelter and clothing for the family. It is significant to state that poor nutrition and hygiene results in poor growth and general underdevelopment which adversely affects academic performance. ${ }^{24}$ The healthy growth and development of every individual is ensured through adequate and quality nutrition right from infancy.

Research has shown that children's dietary and health condition in school largely influence their concentration in the classroom..$^{25}$ It has been revealed that when a woman's financial state improves, her nutritional status also improves. ${ }^{26}$ Hence, she is able to feed her kids well in terms of quality and quantity of food. Parents should be educated on the importance of feeding children with right nutrients.

Aside the nutritional needs, physical activity is important for the total development of a child. There is a suspected positive correlation between physical activity and academic performance. ${ }^{27}$ Such positive influence of physical activity is remarkable since it boosts physical fitness of the individual. This supports the argument to increase physical activity without risk of poor academic performance.

\section{PARENTAL STYLE}

Another significant aspect to discuss is the parenting style adopted by parents. Parenting styles can be described as the kind of upbringing of children or child-rearing method. ${ }^{28}$ Parents vary in performing their roles as parents. Some are warm and accepting while others are cold, unresponsive and rejecting. Child rearing practices have been investigated by several researchers who have identified different ways of parenting. The well-known categories established are authoritarian, authoritative and permissive parenting styles. ${ }^{29}$ Several studies on parenting have been done by other researchers. ${ }^{30}$

\section{Authoritarian style}

Authoritarian parents have firm rules and regulations to establish and sustain desired behaviour. When the necessary standards are not met, the children receive little or no acknowledgement or approval and may even be punished instead to show parental disapproval. There is hardly any dialogue concerning rules and values which restrains the child's selfexpression. Most of such children grow up to be moody, unconcerned and ill-tempered. They usually have low selfesteem. This type of parenting style is associated with socially unacceptable behaviour in children. The children of these parents tend to do less well in school than those of authoritative parents. ${ }^{31}$

\footnotetext{
19 Farid Ghaemi, and Mahbubeh Yazdanpanah. "The relationship between socio-economic status and academic achievement in the classroom among Iranian university students.” European journal of English language and literature studies 2, no. 1(2014): 49-57.

20 Ibid.

${ }_{21}$ Mary N. Gabriel, Lewis M. Ngesu, Isaac Muasya, Timothy Maonga, and Maira J. Mukhungulu. "Parental socio economic status academic achievement in selected secondary schools in urban informal settlements

22 Jeffrey P. Bakken, \& Festus E. Obiakor, (2008). Transition planning for students with disabilities: What educators and service providers can $d o$ ? Charles C Thomas Publisher.

23 Gabriel et al "Parental socio economic status academic achievement in selected secondary schools in urban informal settlements

24 Femi Ogunshola \& A. M. Adewale. "The effects of parental socio-economic status on academic performance of students in selected schools in Edu Lga of Kwara State Nigeria."

25 Pat Pridmore, Impact of Health on Education Access and Achievement: A Cross-National Review of the Research Evidence. Create Pathways to Access. Research Monograph No. 2. 2007.

26 Femi Ogunshola, and A. M. Adewale. "The effects of parental socio-economic status on academic performance of students in selected schools in Edu Lga of Kwara State Nigeria.” International Journal of Academic Research in Business and Social Sciences."

27 François Trudeau, and Roy J. Shephard. "Physical education, school physical activity, school sports and academic performance." International Journal of Behavioral Nutrition and Physical Activity 5, no. 1 (2008): 10.

28 Olivia Akrofi, Parental involvement of School Guidance and Counselling of the Adolescent. Unpublished

29 Diana Baumrind, “Current patterns of parental authority." Developmental psychology 4, no. 1 (1971): 1.

30 S. Aremu and B. Oluwole. "The development and validation and academic performance. 5 Factor Inventory: An unpublished manuscript department of guidance and counselling." University of Ibadan, Ibadan (2000).

31 Luke Mphale, and Mavis Mhlauli. An investigation on students' academic performance for junior secondary schools in Botswana.
} 


\section{Authoritative style}

Parents who adopt this style make conscious effort to raise children to be independent while ensuring that certain boundaries are not crossed. Such parents have a warm and nurturing relationship with their children and they are willing to discuss, set limits and lay down rules with their children. In disciplining the child, they try to reason with the child and help him/her to understand why certain behaviours are acceptable or not. This parenting style produces confident, responsible and independent children. ${ }^{32}$

\section{Permissive style}

Permissive parenting style adopts great tolerance and permits the child excessive boundless liberty without making any demands..$^{33}$ The child receives no guidance on the pattern of behaviour that is socially tolerable and is allowed to do as he/she pleases. Verial believes that children living under this style of parenting often neglect their studies in favour of other social activities. ${ }^{34}$ They have no boundaries and rules, they take interest in other social activities rather than their school work..$^{35}$ It is the worst style to be adopted by any parent. The end result of a child under such parental control is that, he/she becomes self-centred, repulsive and lacks self-control. The child tends to avoid responsibility and often performs poorly academically.

\section{FAMILY SIZE AND POSITION}

Research shows that poor academic performance is influenced by factors such as family size and the position a child occupies in a particular family. ${ }^{36}$ In large families, parents usually pay less attention to individual children. It is sometimes difficult to cater for the developmental needs of all the children. A child's position in the family may also affect his her performance academically. Mostly, the first child gets the attention and devotion of parents more than other siblings in the family. ${ }^{37}$ This is especially so with children in middle to high socio-economic class. Parents out of excitement are determined to provide the first child with all helshe needs. ${ }^{38}$ Asikhia is of the view that such children are overprotected and described as 'spoilt', considering their family background. However, few may strive to achieve academic excellence to encourage other siblings to follow suit. ${ }^{39}$

In recent studies, smaller family size is directly associated with higher academic achievement than large family size ${ }^{40}$ This is because with no or fewer siblings, the child gets the needed attention and care from parents ${ }^{41}$ Furthermore, the limited family resources tend to be enough to cater for smaller family size than that of large families. Asikhia has found that children from larger families have less conducive home environments, behavioural issues and lower levels of educational achievement. Family planning is significant in the maintenance of a model home to enable each member a fair share of the available family resources.

\section{Family Structure}

Asikhia asserts that different family structures produce individuals of various personalities with different approaches towards learning. ${ }^{42} \mathrm{He}$ identifies three types of families; monogamous (nuclear), polygamous and extended. Research has revealed that each type, more often than not, influences academic achievement. In the contemporary world, the nuclear family, which comprises father, mother and children, is the rule. Several studies show that children from nuclear families perform better academically than their counterparts from polygamous families. ${ }^{43}$

Single-parent families also known as alternative family structure is one of the fastest growing family structures in most countries. ${ }^{44} \mathrm{~A}$ family managed by a single parent can be defined as the absence of the father or mother from the family as a result of different situations such as divorce, desertion by a parent, death of a parent and an unmarried

\footnotetext{
Olivia Akrofi, Parental involvement of School Guidance and Counselling of the Adolescent. Unpublished.

Ibid

D. Verial, "The Significance of Packaging." (2013).

Luke Mphale, and Mavis Mhlauli. An investigation on students' academic performance for junior secondary schools in Botswana.

36 Mary Keegan Eamon, "Social-demographic, school, neighborhood, and parenting influences on the academic achievement of Latino young adolescents." Journal of youth and adolescence 34, no. 2 (2005): 163-174.

37 A. O. Asikhia, "Students and teachers' perception of the causes of poor academic performance in Ogun State secondary schools [Nigeria]: Implications for counseling for national development." European Journal of Social Sciences 13, no. 2 (2010): 229-242.

38 Linda Ofosua Adane, "Factors affecting low academic achievement of pupils in Kemp Methodist Junior High School in Aburi, Eastern region. "PhD diss., University of Ghana, 2013.

39 Ibid.

40 Mary Keegan Eamon. "Social-demographic, school, neighborhood, and parenting

41 A. O. Asikhia, "Students and teachers' perception of the causes of poor academic performance in Ogun State secondary schools [Nigeria]: Implications for counseling for national development.

42 Ibid.

43 Ibid.

44 Daniel Andreas Louw. Human development. Pearson South Africa, 1998
} 
parent. ${ }^{45}$ However, single parent families can arise in other ways. For instance, when one parent works away from home or is away for a long period of time, the family waits temporarily and therefore functions as a single parent family. Juvenile delinquency is a common fate of children from single parent families. Such children are noted to have poor relationship with teachers and friends than children from two-parent families. ${ }^{46}$

\section{Parental involvement}

Psychological support from parents is important in promoting the needed environment for academic achievement. Parental involvement in school events have a progressive influence on children's academic achievements. ${ }^{47}$ When parents who were formerly uninvolved in their children's education became involved, their children's literacy improved ${ }^{48}$ Irrespective of income and background, pupils with involved parents to a large extent, get higher marks and test scores than those whose parents are uninvolved. ${ }^{49}$ They exhibit good attitudes and behaviour and strive to further their education. Higher parental involvement is associated with higher educational expectations. ${ }^{50}$ Parental involvement improves a child's educational ambitions, sense of well-being, attitude and readiness for school. Parental involvement is key in every child's schooling because it supports and motivates learners to learn. ${ }^{51}$ Highly educated parents with high income tend to raise their children in the academic culture compared to their counterparts who are illiterates or semiliterates. They provide a conducive learning environment and are prepared to engage teachers to give their children extra tuition where parents have limited time to assist the children at home. ${ }^{52}$

The physical facilities of the home environment correlates with the learner's academic performance and achievements..$^{53}$ These facilities include access to basic needs such as food, clothing and shelter, recreational tools like toys, television, bicycles, computers and learning materials including books. In Winneba (a town in Ghana, West Africa), when the parents got involved in education-related issues concerning their children, their academic performance in school improved. ${ }^{54}$ Also, the involvement of parents in educating their children considerably helps to better their performance than children whose parents do not get involved. ${ }^{55}$ Parents do not have to be experts in the curriculum, assessment or child development to enable them get involved in their children's school activities. They compare test results to detect achievement gaps or ask for their children's progress in terms of academic work and behaviour in order to take appropriate steps to help them. ${ }^{56}$

Psychologists have come to know that some children have temperaments that make them difficult to raise no matter the socio-economic status of parents, such children need greater attention from caretakers. ${ }^{57}$ Consequently, children's academic achievement is greatly based on how well they are managed and catered for in the home. ${ }^{58}$

\section{METHODOLOGY}

The study used a mixed method research approach. Qualitative and quantitative data were attained using questionnaires and interview to provide a vivid understanding of the research problem.

The research focused on the KNUST Primary School, targeting learners with low academic performance together with their parents. Sampling of learners in basic four, five and six was done purposively based on academic

45 Ibid.

46 Chané Kotzé, "The child's psychological experience of the parent's new partner divorce.” PhD diss., 2008.

47 Faisal Ibrahim Mohammad Al-Matalka, "The influence of parental socioeconomic status on their involvement at home." International Journal of Humanities and Social Science 4, no. 5 (2014): 146-154.

48 Eric Dearing, Holly Kreider, Sandra Simpkins, and Heather B. Weiss. "Family involvement in school and low-income children's literacy: Longitudinal associations between and within families." Journal of Educational Psychology 98 , no. 4 (2006): 653.

49 Caine Rolleston, "Educational access and poverty reduction: The case of Ghana 1991-2006." International Journal of Educational Development 31, no. 4 (2011): 338-349.

s0 Domina Thurston, "Leveling the home advantage: Assessing the effectiveness of parental involvement in elementary school." Sociology of education 78, no. 3 (2005): 233-249.

51 Faisal Ibrahim Mohammad Al-Matalka, "The influence of parental socioeconomic status on their involvement at home." International Journal of Humanities and Social Science 4, no. 5 (2014): 146-154.

52 Daniel Yelkpieri, "Socioeconomic status of parents and its effects on students' achievement in the Awutu Senya and Effutu educational directorates in the central region of Ghana." Unpublished Thesis (2016).

53 R. G. Memon, F. M. Joubish, and A. M. Khurram. "Impact of parental socio-economic status on students' educational achievements at secondary schools of district Malir, Karachi." Middle-East Journal of Scientific Research 6, no. 6 (2010):678-687.

${ }_{54}$ A. R. Ghanney, "Effects of home environment on parental attitudes towards the educational attainment of primary school pupils in Winneba Township, Ghana." International Journal of Educational Research 3, no. 2 (2007): 259-266.

55 Adane, "Factors affecting low academic achievement of pupils in Kemp Methodist Junior High School in

56 Olivia Akrofi, (2009). Parental involvement of School Guidance and Counselling of the Adolescent. Unpublished. University of Cape Coast, Cape Coast, Ghana.

57 Daniel Andreas Louw. Human development. Pearson South Africa, 1998.

58 Suresh Kumar N. Vellymalay. "The impact of parent's socioeconomic status on parental involvement at home: A case study on high achievement Indian students of a Tamil School in Malaysia." International Journal of Academic Research in Business and Social Sciences 2, no. 8 (2012): 11. 
performance in the first and second term examinations and the class size.

Close-ended questionnaires were used for easy understanding due to the age level of the learners. Questionnaires were administered to them in groups of 10 from each class to ensure good supervision by the researcher. The administration of the questionnaire took one week to be completed by the learners sampled. The researcher used faceto-face interviews to gather data from parents who had children in basic four to six.

The researcher sought permission from the headmaster of KNUST Primary School before conducting the study. Parents were given prior notice about involving their children in the study. Their own participation in the study was also requested. Confidentiality of information was assured and they consented to participate with their children. The responses in the questionnaire were coded and then entered Statistical Package for Social Sciences (SPSS) software spreadsheet for analysis. Frequency and percentage were employed to analyze the data. Recorded information from interviews were transcribed and coded under themes for analysis.

\section{RESULTS AND DISCUSSION}

This presents a description of data and findings in accordance with the research questions.

Table 1 shows the demographic characteristics of pupils.

Table 1. Demographic characteristics of pupils

\begin{tabular}{llll}
\hline Variable & Category & Frequencies & Percent(\%) \\
\hline Gender & Male & 68 & 56.7 \\
& Female & 52 & 43.3 \\
Age & 8 years and below & 1 & 0.8 \\
& $9-11$ & 84 & 70.0 \\
& $12-15$ & 35 & 29.2 \\
Number of siblings & None & 6 & 5.0 \\
& $1-3$ & 71 & 59.1 \\
& $4-6$ & 39 & 32.5 \\
Lives with biological parents & $7-10$ & 4 & 3.3 \\
& Yes & 114 & 95 \\
Guardian's employment status & No & 6 & 5.0 \\
& Unemployed & 22 & 18.3 \\
& Self-employed & 68 & 56.7 \\
& Public servant & 30 & 25.0 \\
\hline Total & & $\mathbf{2 1 5}$ & $\mathbf{1 0 0}$ \\
\hline
\end{tabular}

Source: Field Survey, 2018

\section{Pupils' Demographic Characteristics}

Table 1 indicates that sixty-eight (57\%) males and fifty-two (43\%) female participants were involved in the study. Majority representing $70 \%$ of pupils were between the age bracket 9-11 years. The table also revealed that, only 6 pupils indicated that they were the 'only child' of their parents, the rest had one or more other siblings. The significance of family size is that the number of children in a family and the ordinal position of a child influence his/her social and personality development. ${ }^{59}$ According to Louw, a child who is alone with parents at home may lack contact with other children and is likely to face difficulty in adjusting. ${ }^{60}$ A significant number, one hundred and fourteen (95\%) pupil respondents, live with their biological parent or parents. Six (5\%) respondents live with other family members such as uncles, grandparents, aunties or family friends. Sixty-eight (56.7\%) parents/guardians were self-employed: mostly petty traders and food vendors who are mainly less educated or low income earners. Hence, they provide little support to their children's academic issues. Families with low socio-economic status encounter financial challenges and often cannot adequately cater for their children's developmental and academic needs.

Table 2 indicates pupils' view of home environmental factors influencing academic performance.

\footnotetext{
59 Daniel Andreas Louw. Human development. Pearson South Africa, 1998
}

60 Ibid. 
Table 2: Pupils'view of home environment factors affecting their performance

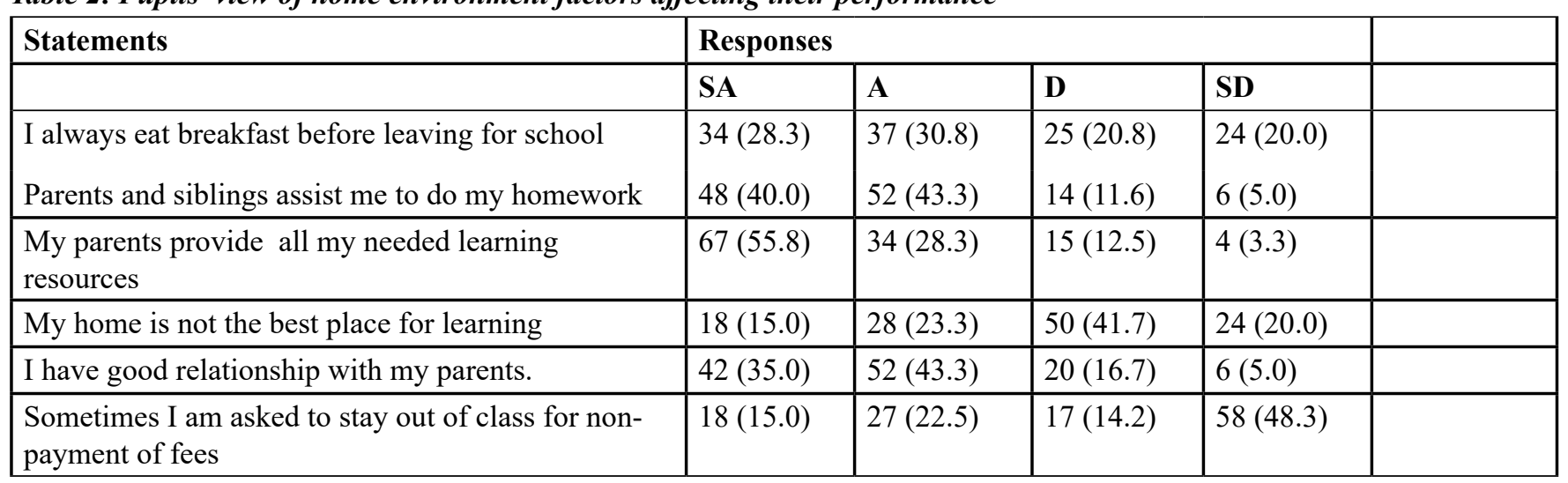

\section{Source: Field Survey, 2018}

\section{SA-Strongly agree, A-Agree, D- Disagree and SD-Strongly disagree}

From Table 2, seventy-one pupils (59.1\%) always ate breakfast before school. Good nutrition is essential for healthy development of the body and brain. Findings from parent respondents revealed that in order to avoid heavy traffic jam and lateness, they prefer to give money to their children to buy breakfast at school. Pupils often resort to junk food and fizzy drinks which contain little or no nutrients. Parents need to make conscious effort to feed their children well before sending them to school.

One hundred of pupil respondents representing $83.3 \%$ were assisted by parents or siblings to do their homework. Assistance from parents and siblings was recorded in homes where parents are educated. Fifty parents representing $83.3 \%$ indicated that they have the skills to assist their children to do their homework and also encourage them to study. However, ten parents representing $16.7 \%$ confirmed that they could not assist their children in doing their homework due to two main reasons: the time they return from work and the nature of exercises given as homework. When interviewed, one father said "Whenever he is given homework, he keeps it in his bag. As a driver, I come home tired. His mother tries to teach him although she is also not well educated." Memon et al. in their findings on the impact of parental socioeconomic status on learner academic achievement found that parents with high socio-economic status often succeeded in preparing their children for school. ${ }^{61}$

One hundred and one of pupil respondents (84.1\%) agreed that they were provided with all the necessary learning resources. Majority of the parents attested to this. Pupils need variety of books, toys and equipment to support their academic work. A significant minority mentioned that they strive to provide their children the adequate learning resources due to their limited income and level of education. One parent said "I have no problem providing my children's basic needs. Except in recent times when my work dwindled." Adequate provision of children's developmental and learning needs can be directly attributed to parental socio-economic status, family size and parental style. ${ }^{62}$

Seventy-four pupil respondents disagreed that their homes were not conducive for learning. Parents who perceived their home environment inadequate for learning attributed it to lack of space and noisy environment. A significant minority, twenty-six (21.7\%) disagreed having a good relationship with parents while ninety-four pupils (78.3\%) agreed. Almost all parents also responded in the affirmative. Parent-child relationship is an important component that significantly affects a child psychologically. However, it can either enhance or disrupt his or her academic performance and total development depending on the adoption of a particular style of parenting by parents.

From Table 2, seventy-five (62.5\%) of pupil respondents disagreed that they had been sent out of class due to non-payment of fees. Forty, representing $66.7 \%$ of parents also agreed that they could pay their children's school fees timely in order to keep them in the classroom. Twenty (33.3\%) parent respondents revealed that occasionally their children had been asked to stay out of the classroom for non-payment of fees. When a child is interrupted in the classroom for non-payment of school fees, helshe becomes emotionally disturbed or feels embarrassed and misses the subjects taught in his her absence.

\section{CONCLUSION}

This study revealed that of the home environment factors, the socioeconomic status of parents has the most influence on academic performance of pupils. Parents who are educated with well-paid jobs are more capable of preparing their children for school by providing basic needs, conducive home environment and adequate learning resources. It

\footnotetext{
${ }_{61}$ R. G. Memon, F. M. Joubish, and A. M. Khurram. "Impact of parental socio-economic status on students' educational achievements at secondary schools of district Malir, Karachi." Middle-East Journal of Scientific Research 6, no. 6 (2010):678-687.

62 Ibid.
} 
was discovered that a significant minority of underachieving pupils did not take good breakfast before school. This undermines the importance of healthy home-made meals in the proper growth and development of pupils.

Few pupils are 'only child' of their parents whereas most of them have one or more other siblings. Smaller family size is directly associated with higher academic achievement than large family size. Thus, the limited family resources may just be enough to cater for smaller family size than large families. The study recommends that parents should be encouraged to provide good nutrition, monitor their children's homework and participate in regular Parent Teacher Association (PTA) meetings to learn more about parental styles and strategies to be more involved in their children's education.

\section{BIBLIOGRAPHY}

Adane, Linda Ofosua. "Factors affecting low academic achievement of pupils in Kemp Methodist Junior High School in Aburi, Eastern region." PhD diss., University of Ghana, 2013.

Akrofi, Olivia. (2009). Parental involvement of School Guidance and Counselling of the Adolescent. Unpublished. University of Cape Coast, Cape Coast, Ghana.

Aliyu, Gambo Adamu. "Influence of socio-economic status on academic achievement of senior secondary students, in Nassarawa zonal education area of Kano State, Nigeria." Asian Journal of Educational Research Vol 4, no. 4 (2016).

Al-Matalka, Faisal Ibrahim Mohammad. "The influence of parental socioeconomic status on their involvement at home." International Journal of Humanities and Social Science 4, no. 5 (2014): 146-154.

Aremu, S., and Oluwole B. "The development and validation and academic performance. 5 Factor Inventory: An unpublished manuscript department of guidance and counselling." University of Ibadan, Ibadan (2000).

Asikhia, O. A. "Students and teachers' perception of the causes of poor academic performance in Ogun State secondary schools [Nigeria]: Implications for counseling for national development."European Journal of Social Sciences 13, no. 2 (2010): 229-242.

Bakken, J. P., \& Obiakor, F. E. (2008). Transition planning for students with disabilities: What educators and service providers can do? Charles C Thomas Publisher.

Barry, J. "Effects of socio-economic status on academic performance." An unpublished MA thesis submitted to Wichita State University, Australia (2005).

Baumrind, Diana. "Current patterns of parental authority." Developmental psychology 4, no. 1 pp. (1971): 1.

Chowa, Gina. "How Do Student and School Characteristics Influence Youth Academic Performance in Ghana? A Hierarchical Linear Modeling of Baseline Data from the Youth Save Ghana Experiment." (2013).

Dearing, Eric, Holly Kreider, Sandra Simpkins, and Heather B. Weiss. "Family involvement in school and low-income children's literacy: Longitudinal associations between and within families." Journal of Educational Psychology 98, no. 4 (2006): 653.

Domina, Thurston. "Leveling the home advantage: Assessing the effectiveness of parental involvement in elementary school." Sociology of education 78, no. 3 (2005): 233-249.

Eamon, Mary Keegan. "Social-demographic, school, neighborhood, and parenting influences on the academic achievement of Latino young adolescents." Journal of youth and adolescence 34, no. 2 (2005): 163-174.

Gabriel, Mary N., Lewis M. Ngesu, Isaac Muasya, Timothy Maonga, and Maira J. Mukhungulu. "Parental socio economic status academic achievement in selected secondary schools in urban informal settlements in Westlands Division, Nairobi County.” (2016).

Ghaemi, Farid, and Mahbubeh Yazdanpanah. "The relationship between socio-economic status and academic achievement in the classroom among Iranian university students." European journal of English language and literature studies 2, no. 1 (2014): 49-57.

Kotzé, Chané. "The child's psychological experience of the parent's new partner divorce.” PhD diss., 2008.

Louw, Daniel Andreas. Human development. Pearson South Africa, 1998.

Memon, G. R., F. M. Joubish, and A. M. Khurram. "Impact of parental socio-economic status on students' educational achievements at secondary schools of district Malir, Karachi." Middle-East Journal of Scientific Research 6, no. 6 (2010): 678-687.

Mphale, Luke Moloko, and Mavis B. Mhlauli. “An investigation on students' academic performance for junior secondary schools in Botswana." European Journal of Educational Research 3, no. 3 (2014): 111-127.

Muruwei, Meshach. "Parents' level of education and Senior Secondary Students' Academic Performance in English Language in Bayelsa State, Nigeria." Journal of Research in national development 9, no. 2 (2011): 302-305.

Nyarko, Kingsley. "Parental school involvement: The case of Ghana." Journal of Emerging Trends in Educational Research and Policy Studies 2, no. 5 (2011): 378-381.

Ogunshola, Femi, and A. M. Adewale. "The effects of parental socio-economic status on academic performance of 
students in selected schools in Edu Lga of Kwara State Nigeria." International Journal of Academic Research in Business and Social Sciences 2, no. 7 (2012): 230-239.

Pridmore, Pat. Impact of Health on Education Access and Achievement: A Cross-National Review of the Research Evidence. Create Pathways to Access. Research Monograph No. 2. 2007.

Rolleston, Caine. "Educational access and poverty reduction: The case of Ghana 1991-2006." International Journal of Educational Development 31, no. 4 (2011): 338-349.

Sirin, Selcuk R. "Socioeconomic status and academic achievement: A meta-analytic review of research." Review of educational research 75, no. 3 (2005): 417-453.

Trudeau, François, and Roy J. Shephard. "Physical education, school physical activity, school sports and academic performance." International Journal of Behavioral Nutrition and Physical Activity 5, no. 1 (2008): 10.

Vellymalay, Suresh Kumar N. "The impact of parent's socioeconomic status on parental involvement at home: A case study on high achievement Indian students of a Tamil School in Malaysia." International Journal of Academic Research in Business and Social Sciences 2, no. 8 (2012): 11.

Verial, D. "The Significance of Packaging.” (2013).

Yelkpieri, Daniel. "Socioeconomic status of parents and its effects on students' achievement in the Awutu Senya and Effutu educational directorates in the central region of Ghana." Unpublished Thesis (2016). 